\title{
How to uphold standards of medical education in Nepal: Some recommendations
}

\author{
Baral P
}

Lecturer, Department of Anatomy, Manipal College of Medical Science, Pokhara, Nepal

$\mathrm{M}$ edical education has been a subject of the highest concern to all the people as it produces excellent doctors who serve the people. Critics' remark say that the current medical education system has not served well, the general standards of the medical graduates who pass out of our medical colleges in Nepal is low as compared to international standards, both in skill and in knowledge. Everybody talks about it but nobody does anything about it.

Medical education system should have caught up with vision of a better society where in there is a commitment to important principles of social justices, but in reality we see intolerable in equities in the distribution of health resources with in our country.

The medical education has to keep to certain standards is a truism. Medical educationist should provide the medical graduates with enough skills and knowledge so that $\mathrm{s} /$ he can practice his arts and science confidentially and with the necessary skill. Regulation of standards can be achieved by inspection, control and rectification.

Three different bodies are regularly checking the standards of education of medical and dental colleges of Nepal.

1. Higher Technical Education Evaluation and Monitoring Committee.

2. The concerned University.

3. Nepal Medical Council.

After receiving permission to start the medical colleges the concerned institutions have to undergo yearly visits till it gets permanent recognition. This has helped to maintain standards ${ }^{1}$.

Nepal Medical Council is an effective body today and can help in preventing downslide in standards likely to occur, when a large number of medical colleges are opened throughout the country. Medical Council should carry out inspection periodically and suddenly without prior information to the concerned college.
Standards of medical college in Nepal are very pathetic. First of all there are no adequate faculties to teach students. Student, teacher's ratio is very poor thus the number of student's intake by medical colleges should be restricted by monitoring strictly.

Entry of suitable persons to Council should be done by voting for doctors with clean image during Council elections and appointing rest of the members from different fields and represent different regions. This is because good persons can monitor standard of medical colleges honestly.

The licensing examination for medical practioners is also playing some role in upholding standards of medical education to some extent. It should be made more qualitative.

The Nepal Medical Council should also conduct examination for specialist registration following post graduate trainings so that uniformity of standards could be maintained.

For upholding of standards of medical education it is essential from an international point of view, to adopt continuous quality improvement system. Under this system postgraduate faculties/ doctors have to appear in certification exam every five years to renew the working license. If $\mathrm{s} /$ he fails in test, s/he can not continue professionally till $\mathrm{s} /$ he passes the test again. The system compels the faculty/doctor to update him/her self with the most recent information and knowledge.

The other regulating body is the university which provides affiliation to the medical colleges. University can exert control on medical education through their Academic Councils and Faculty Board. This has been effective method of maintaining standards and also updating curricula.

Correspondence

Dr. Prakash Baral

Lecturer, Department of Anatomy

Manipal College of Medical Science, Pokhara, Nepal

E-mail: prakashbara12002@gmail.com 
We in Nepal have been mainly influenced by the medical practices introduced by the British to the Indian subcontinent. Problem based learning which had been introduced as far back as the late seventies at McMaster has spread to different corners of the globe and is being utilised for teaching/learning not only in medicine but also in various others fields. We in Nepal have been toying with its used for some years. More extensive utilisation appears certain in the future to make medical curricula up to the international standards ${ }^{2}$.

In upholding standards, role of medical educationists is also important. They should change medical curricula to make medical education more public health oriented. Medical men should possess knowledge of public health problems and know -how to tackle them.

While formulating postgraduate curriculum one paper should be on learning objectives and teaching methods. Post graduate course duration should be made of four years, out of which followed for first six month basic sciences should be taught and examination by an on basic sciences be taken. After passing basic science paper one can go for postgraduate's clinical training.

The university should make provision for medical faculties undergo training compulsorily on teaching methodology.

The author of this article believes that if we abide by above mentioned recommendations then only we can improve the standard of our medical education in Nepal.

\section{References}

1. Dixit H. Development of medical education in Nepal. Kathmandu University Medical Journal. 2009;7(25): 8-10.

2. Dixit H. Medical education: Historical perspective. Kathmandu University Medical Journal. 2009;7(25):1. 